\title{
An astonishing journey into reproductive genetics since the 1950's
}

\author{
Robert G. EDWARDS* \\ Reproductive BioMedicine Online, Cambridge, UK
}

\begin{abstract}
Training in genetics in Edinburgh in the 1950s led to a $\mathrm{PhD}$ on the developmental biology of mouse embryos with unusual chromosomal complements. Fundamental aspects of reproduction under study included ovulation induction, oocyte maturation and embryonic growth to blastocysts. It led to the introduction of embryo stem cells, preimplantation genetic diagnosis, the exact timing of human oocyte maturation in vitro and studies on fertilising human eggs in vitro to alleviate human infertility. My work was helped by studies on sperm capacitation and the physiology of fertilization in domestic and laboratory species by Thibault, Dauzier, Austin, Chang, Yanagimachi and others. I met Charles Thibault at a meeting in Cambridge U.K. where he criticised the work of Moricard, and then frequently on lecture circuits. Impressed by his grandeur but not his doubts about human IVF, Steptoe and I initiated human embryo transfers and the birth of Louise Brown. Details of her pregnancy had to be confidential to reduce the risks of abortion associated with the intrusion of numerous newsmen chasing the story. I was compelled to withold this information at a meeting in Paris in the late 1960s when I had to leave early to return to UK. This omission annoyed Thibault and led to our celebrated quarrel. I felt he failed to appreciate the complexity, the implications of this pregnancy and an astonishing future. So much was at stake, including IVF, stem cells and preimplantation diagnosis to help millions of patients. Some months later, our dispute was ended even if somewhat formally. Nevertheless it is a pleasure to recall how we shared so much in common. I still admire him as an inspiration to many colleagues and students, and a father figure in French agricultural research.
\end{abstract}

human / embryo / reproductive genetics / stem cells / in vitro fertilization

I am honoured to be at this meeting to salute the life of Charles Thibault since I knew him over a period of 40 or 50 years. Ours was not an entirely smooth relationship, but I think we both had mutual respect for each other. I also believe we each recognized a worthy opponent or colleague when difficult times arrived. In a sense, although I never formally told him this, it was his work, and that of Chang [1], and of Austin [2], on the capacitation of sperma- tozoa which set me off on my travels into human IVF.

\section{MEETING CHARLES THIBAULT}

My first meeting with Charles occurred in the 1950's. I was a young Ph.D. student, ex-British army, looking for a career in Edinburgh, having nearly failed my BSc and trying to make amends with a good

* Corresponding author: cb@rbmonline.com 
Ph.D. I worked under the overall guidance of Professor Conrad Waddington, in Edinburgh, and my supervisor Alan Beatty had interested me in mouse embryology as a topic for my Ph.D. Waddington was an unusual man. He taught me ethics, modern art and embryology! His library had shelves full of ethics and philosophy and he insisted that we should read them in our Ph.D. years. He was a brilliant developmental biologist, and even today, investigators accept his concepts on gene silencing and how brain tissue forms out of stem cells.

In a sense, working with Waddington and Beatty was bound to lead me to Charles Thibault. Waddington was brilliant in developmental genetics, and introduced epigenetics 40 or 50 years ago. The last time I heard him lecture, he described how he had cultured some Drosophila embryos at a temperature higher than normal. As the eggs hatched, instead of having two eyes, the offspring had two legs. After proving that he had activated a gene displaying Mendelian segregation, he realised our ancestors millions of years ago were little worms in which all the first body segments produced legs. Evolution had then incorporated the segment into the brain to form eyes in mammals. He had reversed this entire process yet the original genes were still there but were normally silenced during embryogenesis. He soon proved he had uncovered a gene that had been silenced over thousands of years, and how it remained permanently active in all descendants when it was uncovered by heating those embryos. Waddington's hypothesis was recently confirmed when chickens were given teeth by simply ending the epigenetic suppression of the two genes by injecting a few mouse stem cells into an early chick embryo. I understand the last bird to have teeth was Archaeopteryx. All this research has revealed that 'epigenetic' syndromes in embryos, as Waddington called them, may arise by gene silencing rather than by mutation. As I finished my Ph.D., thoughts such as these dominated my reproductive knowl- edge which was hardly the best approach to working with reproductive biologists!

So my invitation to a meeting on reproductive physiology in Trinity College, Cambridge, the first I had ever received, soon revealed my background knowledge differed greatly to that of Charles Thibault. In the big wide world, geneticists and reproductive biologists co-existed but rarely met. Reading Charles' papers, I thought of him as a man interested in reproductive physiology and who was trying to come to terms with genetics, and especially mathematical genetics on cattle breeding. He had studied gene activation in pronuclei. He later became very interested in cattle IVF, and joined with Bunny Austin and Min Chueh Chang and worked with Dauzier on what was later called 'capacitation' [3]. At the meeting in Cambridge, Britain's leading reproductionists were present including John Hammond, Alan Parkes and Thaddeus Mann among others. There were several distinguished Frenchmen too whom I did not know. Among them were Charles Thibault and Rene Moricard.

Half-way through the meeting, Moricard gave a lecture with illustrations, and claimed how he had fertilised the rabbit egg in vitro. To my amazement, as Moricard was still speaking, a delegate sitting near to me jumped to his feet shouting (in Franglais) that 'it is a lie'. It was a tall Frenchman who continued shouting "He is wrong, he is wrong, he is wrong!" All this was outside my meagre experience. Someone told me that this delegate was Charles Thibault. He was obviously excitable, yes, but clearly passionate about research. Just like Waddington! An hour or so later, I went very humbly to him - remember, I was a very recent Ph.D. with ideas on changing chromosomes in mouse embryos and applying the newly-invented autoradiography to study spermatogenesis in mice. He spoke with me just a little but most courteously. He was very kind. He listened - a nice characteristic, and encouraged me. I remember showing him some data of ours 
on the use of radiolabelled precursors and autoradiography to measure RNA and protein turnover in mouse eggs. He seemed to be impressed and asked "Was I lecturing here?" No, I had not got started on that pathway as yet. He told me more about his work, about how he was moving into in vitro studies [4]. Bunny Austin and Min Chueh Chang were also there. Little did I know that one day Bunny would become my professor. I have often thought he was one of the very finest men I ever knew. Chang was also very impressive and told me he loved Cambridge and that he had worked there for several years. These three men were pioneers all interested in the same subject, and all worked in the same field. They were looking at the pre-events to fertilisation, using in vitro systems although in the end they were forced to return to in vivo systems.

Charles and I did not meet over the next few years. The stories I heard about him were very varied. I recollect being told there had been very sharp arguments in Paris over Moricard's claims and that he had been suspended from his post. Who took this decision remains unknown to me, but I often wondered if Charles was part of the criticism. And in any case, I was following some of the early pioneers by moving to in vitro work in mice, especially on oocyte maturation. As Gregory Pincus had discovered some years previously, rabbit oocytes matured spontaneously without any need for added hormones. Many French and UK teams were also working on ovarian stimulation in farm animals and it was clear that Charles was deeply involved in these ideas. We had superovulated mice, using pregnant mares serum as an FSH source and human chorionic gonadotrophin to induce multifolliculation and ovulation in adult mice. Litters of 50-60 fetuses would have been born if we had not autopsied the mothers three-quarters through gestation. Everything that happened to our mice, happened again in humans five years later when Gemzell and others started superovulating women using extracts of human pituitary glands as an FSH source and HCG to induce ovulation. Even today, we cannot control the number of human eggs ovulated after the use of gonadotrophins.

\section{WORKING WITH EMBRYO STEM CELLS AND CONTEMPLATING HUMAN STUDIES}

By now, I had become familiar with the sheer scale of human infertility and was already contemplating attempts to alleviate using human fertilization in vitro. Briefly, this work led to the maturation of human oocytes in vitro - they required $37 \mathrm{~h}$ and not $12 \mathrm{~h}$ as in mice. It also gave me the opportunity to inseminate them in vitro when they were mature and ready for fertilization. I was moving straight back to work done previously by Thibault, Dauzier, Austin, Chang and Yanagimachi [1-9].

At this critical juncture for me in 1963, I received a letter from a biochemist in Glasgow called John Paul. He had followed some of my studies on trying to get cell lines from fertilised mouse eggs and wished us to work together for a year to grow embryo stem cells in vitro. I had wished to see if we could grow cells producing blood or nerves in vitro, and so did he. So we teamed up, with Robin Cole as well, three of us. During my sabbatical, we managed to produced stem cell lines from disaggregated rabbit inner cell mass which would not stop dividing while remaining undifferentiated in vitro for 200 or more generations. If cultures were made from intact blastocysts, inner cell mass cells differentiated into blood islands, nerves, phagocytes, muscleliterally every tissue in the body. We could hardly believe our eyes at these fantastic results. I began to realise my research was moving towards clinical studies and the thought of having stem cells capable of colonising damaged tissues in sick people fascinated me.

What has all this to do with Charles Thibault? It spelt we were now on very 
different tracks. I heard he was becoming a senior civil servant in Agriculture, and a powerful man in French science. But I felt my ideas would be somewhat alien to him. This feeling grew as I moved back to Cambridge to rejoin Bunny Austin and Alan Parkes. Our papers on stem cells were now published in leading journals including the Journal of Reproduction and Fertility and Developmental Biology (see review by Edwards [10]). In fact, the first paper on human stem cells published by Thomson in the USA in 1995 was a carbon copy of our paper in Developmental Biology 35 years earlier. Everything we did, he had copied, and he did not refer to our foundation work. My pathway had left agriculture for good and ethics were coming up very fast.

In Cambridge, I was delighted to meet young students who were fascinated by these new ideas and wished to do their $\mathrm{Ph} . \mathrm{D}$. on those topics. Good Ph.D. candidates want to work. They are fabulous and my pace of research was changed for good as they began their Ph.Ds. I wanted to test embryo stem cells in mice by placing them in a recipient blastocyst carrying distinct marker genes. Would they colonise body tissues, just as those from cultured rabbit blastocysts had produced nerves, muscle, etc.? I offered this subject to Richard Gardner for his Ph.D. He accepted. It would involve operating on blastocysts.

Initially, we worked together to establish the correct operative procedures for operating on blastocysts and decided to excise small pieces of trophectoderm from rabbit blastocysts. The excised tissues were then stained for sex chromatin, so we could identify male embryos (negative) and female embryos (positive). Each of the sexed blastocysts transferred to recipients produced male or female offspring exactly as we predicted. The world of preimplantation genetic diagnosis in mammals was opened! It could help avoid the birth of children with severe inherited disorders. What would Charles have thought of that? I often wonder. Then Richard turned to his Ph.D. and injected single stem cells into mouse blastocysts. He discovered they formed chimaeras in which descendants of the donor cell had colonised virtually every tissue in the body. This work was the forerunner of new concepts on applying gene recombination to mammalian embryos.

\section{MOVING TO HUMAN FERTILIZATION AND PREIMPLANTATION EMBRYOGENESIS IN VITRO}

Events were moving even faster since I needed human blastocysts to help the infertile patient, introduce sexing and wider aspects of PGD, make human stem cells and also bring human conception into the care of science and medicine. It was time to fertilise human eggs in vitro. Cutting a long story short, another Ph.D. student, Barry Bavister, and I decided to inseminate a dozen or so human oocytes which had been matured in vitro. Previously, occasional mature human eggs had been seen with two nuclei after insemination but fertilization could not be proved for certain. This time, we witnessed every stage of sperm attachment to the zona pellucida, their penetration to the perivitelline space, entry into the eggs and the formation of two pronuclei with sperm tails in the ooplasm - a certain test of fertilization. My world of human embryos was opening as I watched these beautiful sights.

Indeed, my world was now full of exciting research into endless topics with a succession of Ph.D. students. It was full of wonderful events. The first triploid embryos were achieved in mice, mouse spermatozoa were labelled with adenine-C14 to measure their migration through the testis and epididymis, the first adult mouse responded to injected gonadotrophins, the first stage of diakinesis was seen in a maturing oocyte, astonishing stem cells grew in vitro, Richard produced his first chimaera and now human eggs were fertilised in vitro. I was prepared 
to defend my ethical position on these matters as I had watched Waddington do in discussions with Churchmen, and was determined to cope with extreme Press attention by debating them on television or in articles. Reporters were everywhere! My Ph.D. students told me they had literally thrown out intruding reporters from the laboratory. Nor was there any doubt that many scientists objected to these plans of establishing human life in vitro. Suddenly, some people were on my side even if a majority were against. I remember sitting with John Paul in Glasgow just as the first stem cells had grown in vitro and showing him the first human egg to mature to metaphase 2 and extrude its first polar body. Nobody believed a word we said on stem cells or IVF as sheer non-comprehension afflicted many of my critics. How about Charles Thibault? I considered he would be critical even as I came to Paris several times to lecture on all these ideas. It was all a very long way from studies on fertilization in mice and cattle.

Jean Purdy joined our small team, followed by Patrick Steptoe, a leading gynaecologist and pioneer in endoscopy especially laparoscopy. We now formed a small, complete unit capable of investigating human IVD biomedically and initiating work on alleviating human infertility. Indeed, I was in a state of euphoria over stem cells to cure disorders, IVF for infertility and preimplantation genetic diagnosis to avoid conceiving children with severe deformities. I thought we would get a million pound grant for these fantastic new approaches in medicine, but instead got rejection everywhere, even from the UK Medical Research Council who said that laparoscopy was dangerous (yet Patrick was the world authority with 500 or more cases already) and that I should study Rhesus monkeys before humans (a waste of time since the embryo, the cervix uteri, and the form of implantation differ so much from their human equivalents). Nobody would fund us; all granting agencies were fully negative. To my astonishment, an
American philanthropist lady phoned me up unexpectedly one night when at home. She so approved our work that she wished to send us funds to proceed with IVF. This typical American attitude, where a philanthropist wishes research to progress, is really wonderful. Why do most of them live in the USA? They give their money gladly for research.

\section{WORKING WITH PATRICK STEPTOE AND JEAN PURDY}

Let me finish the scientific aspects of early IVF which took place in the Oldham and District General Hospital, Lancashire, many endless miles from Cambridge. Patrick's laparoscopy was fantastic as he extracted numerous oocytes from our patients stimulated with HMG and HCG. The great majority of eggs were fertilised in vitro, and many developed to blastocysts a beautiful sight. A few even grew to day 9 after hatching from their zona pellucida. Their growth was wonderful and their morphology, cell and nuclear structure were fully normal. None implanted. Our dismal failures to establish pregnancies from a transferred human embryo did not go unnoticed by the Press. Reporters were everywhere, querying and criticising. Our critics were having a field day giving us free advice on human embryos even though they had never seen any.

Our major problem with establishing pregnancies in our patients was endocrinological. Injected gonadotrophins invoked an oestrogen-related short luteal phase, often so short that menstruation occurred 56 days after ovulation. We decided to replace single embryos in their mothers and sustain the luteal phase with Primulot depot, a Schering product. We tried all approaches to avoid the use of gonadotrophins alone, combining them with clomiphene, tamoxifen, bromcryptine, and using different patterns of stimulation. No pregnancies emerged. Attempts were made at what came to be called GIFT, oocyte 
donation, injections of $\mathrm{HCG}$ at mid cycle to regularise the cycle. Levels of Primulot depot were reduced, and to our delight a patient became pregnant. The fetus was seen beautifully on ultrasound but it turned out to be ectopic and had to be removed.

As Patrick's time in the National Health Service shortened, it now seemed best to test natural cycle IVF with its normal luteal phase, applying a modified and rapid assay for $\mathrm{LH}$, based on a commercial assay. $\mathrm{LH}$ assays could be done in ca. $45 \mathrm{~min}$ so the onset of the LH surge in mid-cycle could be detected in time to prepare for laparoscopy and embryo culture. Leslie Brown was the second patient on this treatment. We know she was pregnant in 15 days Unable to keep her secret, Leslie or someone close to her told her friends about her wonderful pregnancy, and the Press knew of it a month of so later. We begged them to keep the news confidential, otherwise the publicity involving the Browns could become so stressful as to lead to abortion. They agreed, bless them, until Lesley was almost ready to deliver. This example shows how the Press can be immensely responsible and I have never forgotten this episode.

Active research continued in our Cambridge laboratories. Stem cells were exploding in the hands of another of my Ph.D. students, Peter Hollands, He grafted blastocyst stem cells or those from newly implanted fetuses into irradiated mice. Miracles occurred all over again. Descendants of donor stem cells colonised liver, spleen and bone marrow in $48 \mathrm{~h}$, and were producing markers detectable in the recipients blood in 4-5 days. They saved most of irradiated mice from death and sustained them for a full lifetime. They didn't cause cancers, they were not rejected in intact recipients, and they did not need directing to the right place. They apparently migrated directly to the damaged organs and mended those irradiated mice. These astonishing situations have been found today in many other similar studies. All my hopes of stem cells were being vindicated. It was essential to know that human blastocysts established in vitro would develop normally to term. Without them, and this knowledge, they would have been useless. So we were doing all we could to help Leslie and John Brown with their pregnancy. So much depended on it - IVF, PGD, stem cells, chromosomal analyses on embryos, and the ethical need to bring biomedicine into human conception.

\section{CONTROVERSY IN PARIS}

When Leslie was in her third trimester, I received invitations to lecture in London and Paris on human IVF. Faced with the risk of disclosure of Leslie's pregnancy, my wish was to cancel my attendance of both meetings. Patrick and Jean prevailed on me to go even though we were inundated with patients and Press. It would hamper our work to be absent from Oldham so I would have to take the train to London and back, or fly out to Paris and back on the same day. Warning my colleagues in London and Paris in advance about my very short stay, I agreed to go but agreed with Patrick and Jean that the earlier work would be presented, without a single word about Leslie and John Brown to ensure they would be protected from massive public attention. The London lecture went very well. My lecture in Paris was given, then everyone disappeared to lunch. Assuming they had understood my need to get back early, I took a taxi to Charles de Gaulle airport and flew back to Manchester. I discovered later that my French hosts had seemingly misunderstood my intentions, yet had left me isolated after my lecture. Charles was furious at my early departure and let me know it in a letter. He received an answer in the same terms. I genuinely felt he was lost in the modern world, without any concept of the significance of what we were trying to do or how we were coping with an invading horde of Pressmen and the possible effects on mass publicity on our patients in mid-pregnancy. Lesley Brown could have lost her pregnancy under such immense pressures. 
Was Charles right to hesitate over human IVF and show such a lack of understanding about the developing situation in Oldham? He had not really entered into it. It is very different from IVF in mice or cows. Working in genetics, I well knew the implications of our work and the vast number of infertile patients desperately awaiting treatment. Confidentially was imperative on some occasions, and my trips to London and Paris threatened all our previous work if full details were disclosed. Charles should have understood this; my London colleagues certainly did released. Pressures can also be exerted on investigators and we were no exception as hundreds of reporters gathered around the Oldham and District General Hospital a few weeks later as Leslie entered her final stages of pregnancy. I am sure that Andre van Steirteghem and Paul Devroey faced the same pressures as they invented ICSI.

Clearly, my relations with Charles had degenerated. We worked on different planes. Slowly, our disagreement began to warm. We had occasional lunches together at various conferences if I recall correctly. We also met in several meetings where I wanted to collect opinions from various European countries on the advisability of forming a European Society with its own journal. I remember with pleasure founding ESHRE with Jean Cohen. Wishing to gain wide acceptance from fellow Europeans on the advisability of a new European journal named Human Reproduction, we had organised several meetings in various nations. Again, if I recall correctly, Charles was among the very few French people at one of these meeting who was highly critical and voted against.

\section{CONCLUSIONS}

I believe Charles and I would have worked together closely if human research had not beckoned me. As it was, my line was to use animal models to help understand human conception and development.
In contrast, Charles seems to have remained deeply rooted in the world of research and practice in farm animals and the regulation of farming practice. Yet the switch from animals to humans is an enormous jump especially in relation to human conception in vitro.

What did Charles think of today's world of cloning, microarrays, designer babies. Would he have supported a French Parliamentary Bill on therapeutic cloning as occurred in UK? If he had, he would have put all his weight behind it, as he clearly has done throughout his career in managing major aspects of French agriculture. This is what still makes me admire him, despite our differences. I believe he would do nothing by halves, and was a born leader. He was also clearly admired by his many students. He was simultaneously a leader in French science from the front, and displayed an ability in practice to grow in stature among administrators and politicians. He was an undoubted founder investigator in my field, there can be no doubt about that. And until my career took me into work that was ethically controversial, he and I worked happily together. So let us salute the memory of a very fine Frenchman and the wonderful things he achieved in his career.

\section{REFERENCES}

So many investigators contributed to oocyte growth and maturation, and to the achievement of fertilization in vitro that it is impossible to quote more than a few. Detailed lists can be found in the articles listed below.

[1] Chang MC. Hormonal regulation of sperm capacitation. In: Raspé G(Ed), Schering Symposium on Mechanisms Involved in Conception, Advances in the Biosciences, Pergamon Press, New York, 1969, 4, p12-20.

[2] Austin CR. The Mammalian Egg. Blackwell, Oxford University Press, UK, 1961. 
[3] Dauzier L, Thibault C. New data on the in vitro fertilization of rabbit and ewe ova. $\mathrm{C} \mathrm{R}$ Hebd Seances Acad Sci 1959, 248: 26552656.

[4] Thibault C. La parthénogenèse expérimentale chez le lapin. C R Hebd Seances Acad Sci 1947, 224: 297-299.

[5] Thibault C, Dauzier L. Analyse des conditions de fécondation in vitro de l'oeuf de lapine. Ann Biol Anim Biochim Biophys 1961, 1: 277-294.

[6] Thibault C. Normal and abnormal fertilization in mammals. In: Schering Symposium on Mechanisms Involved in Conception, Parthenon Press, New York, 1971, 6: 63-85.
[7] Thibault C, Gerard M, Menezo Y. Acquisition par l'ovocyte de lapine et de veau du facteur de décondensation du noyau de spermatozoïde fécondant (MPGF). Ann Biol Anim Biochim Biophys 1975, 15: 705-714.

[8] Yanagimachi R. Acceleration of the acrosome reaction and activation of guinea pigs spermatozoa by detergents and other reagents. Biol Reprod 1975, 13: 519-526.

[9] Thibault C. Hammond Memorial Lecture. Are follicular maturation and oocyte maturation independent processes? J Reprod Fertil 1977, 51: 1-15.

[10] Edwards RG. Aspects of the molecular regulation of early mammalian development. Reprod Biomed Online 2003, 6: 97-113. 